\title{
Response of Green Beans to Acidity Factors in Six Tropical Soils ${ }^{1,2}$
}

\author{
Fernando Abruña, Raúl Pérez-Escolar, José Vicente-Chandler, \\ Jacinto Figarella, and Servando Silva ${ }^{8}$
}

\section{INTRODUCTION}

Factors associated with soil acidity such as toxic concentrations of aluminum and manganese, deficiencies of calcium and magnesium, and fixation of phosphorus, are major causes for low crop yields on many soils of the Humid Tropics. The natural high acidity of the Ultisols and Oxisols of these regions is increased further by heavy fertilization with residually acid materials.

Little information is available as to the specific factors of acid soil infertility that influence yield and composition of tropical crops grown under intensive management. In Puerto Rico, Abruña et al. (3) found that yields of heavily fertilized Napier grass growing on an acid Ultisol were doubled by liming. Abruña and Vicente-Chandler (1) found that yields of heavily fertilized sugarcane growing on a typical Ultisol increased from 1 to 47 tons per acre yearly with increasing exchangeable base and decreasing exchangeable aluminum content of the soil. Abruña, et al. (2) reported that intensively managed coffee responded strongly to liming on acid soils high in manganese and did well at very high acidity and exchangeable aluminum levels in soils low in manganese. Abruña, et al. (4) found that tobacco responded strongly to liming on three Ultisols and an Oxisol and that response was closely related to the aluminum and manganese content of the soils. Abruña et al. (5) found that corn responded very strongly to liming on eight Ultisols and Oxisols typical of the Humid Tropics and that response was closely related to exchangeable aluminum and base contents of the soils.

The present study determined the effects of soil acidity on yields and

1 Manuscript submitted to the Editorial Board July 18, 1973.

2 This report covers work carried out cooperatively between the Agricultural Research Service, USDA, and the Agricultural Experiment Station, Mayagüez Campus, University of Puerto Rico, Rfo Piedras, P.R., partially funded by the U.S. Agency for International Development under research contract csd-2490 entitled: Soil Fertility Requirements to Attain Efficient Production of Food Crops on the Extensive, Deep, Well-Drained but Relatively Infertile Soils of the Humid Tropics.

Soil Scientist, ARS, USDA, Soil Scientist, Puerto Rico Agricultural Experiment Station and Soil Scientist, Chemist and Agricultural Technician, ARS, USDA, respectively. 
foliar composition of green beans grown in the field on five Ultisols and an Oxisol typical of the Humid Tropics.

\section{MATERIALS AND METHODS}

Characteristics of the experimental soils are shown in table 1 .

Experiment sites were divided into from 30 to 60 plots of 12 feet $\times 12$ feet each, arranged in a completely randomized design. Increments of limestone were added as required to provide a wide range in soil acidity and percent base saturation. The limestone was thoroughly worked into and mixed with the upper 6 inches of soil.

TABLE 1.-Characteristics of the soils at the various experimental siles

\begin{tabular}{|c|c|c|c|c|c|c|}
\hline Soil type & Location & Classification & Origin & $\begin{array}{c}\text { Organic } \\
\text { matter }\end{array}$ & $\left|\begin{array}{c}\text { Cation } \\
\text { ex- } \\
\text { change } \\
\text { capacity }\end{array}\right|$ & $\begin{array}{c}\text { Bulk } \\
\text { density of } \\
\text { undisturbed } \\
\text { soil }\end{array}$ \\
\hline & & & & Percent & $\begin{array}{l}M I \mathrm{eq} / \\
100 \mathrm{~g}\end{array}$ & $\mathrm{G} / \mathrm{cm}^{2}$ \\
\hline $\begin{array}{l}\text { Humatas } \\
\text { clay }\end{array}$ & Orocovis & $\begin{array}{l}\text { Typic tropo- } \\
\text { humults }\end{array}$ & Volcanic tuffs & 3.0 & 15 & 1.1 \\
\hline Corozal clay & Corozal & $\begin{array}{l}\text { Aquic tropu- } \\
\text { dult }\end{array}$ & $\begin{array}{l}\text { Tuffaceous ma- } \\
\text { terial }\end{array}$ & 4.0 & 19 & 1.2 \\
\hline $\begin{array}{l}\text { Corozal clay } \\
\text { subsoil }\end{array}$ & Corozal & $\begin{array}{l}\text { Aquic tropu- } \\
\text { dult }\end{array}$ & $\begin{array}{l}\text { Tuffacenus ma- } \\
\text { terial }\end{array}$ & 2.5 & 16 & 1.3 \\
\hline Coto clay & Isabela & $\begin{array}{l}\text { Tropeptic } \\
\text { haplorthox }\end{array}$ & $\begin{array}{l}\text { Limestone } \\
\text { quartzitic } \\
\text { sand deposits }\end{array}$ & 2.0 & 5 & 1.1 \\
\hline $\begin{array}{l}\text { Los Guineos } \\
\text { clay }\end{array}$ & Jayuy & $\begin{array}{l}\text { Epiaquic tro- } \\
\text { pohumults }\end{array}$ & $\begin{array}{l}\text { Tuffaceous ma- } \\
\text { terial }\end{array}$ & 8.1 & 16 & 1.1 \\
\hline $\begin{array}{l}\text { Corozal clay } \\
\text { level }\end{array}$ & Corozal & $\begin{array}{l}\text { Aquic tropı- } \\
\text { dult }\end{array}$ & $\begin{array}{l}\text { Tuffaceous ma- } \\
\text { terial }\end{array}$ & 4.7 & 19 & 1.2 \\
\hline
\end{tabular}

The soil in all plots of all experiments was sampled 6 months after liming to determine its acidity status. Twelve cores were taken in each plot at 0 to 6-inch depths, composited, air dried, and screened through a 20-mesh sieve. Cation-exchange capacity was determined by both the ammonium acetate extraction procedure and by sum of cations. Calcium and magnesium were determined by the Versenate titration method using Calcein as calcium indicator and Calmagite as $\mathrm{Ca}-\mathrm{Mg}$ indicator. Potassium was determined by flame photometry. Exchangeable aluminum was extracted with $1 \mathrm{~N}$ potassium chloride and determined by the aluminum method. Soil reaction was measured with a glass-electrode pH-moter using a 1:1.j soil-water suspension.

Beans of the Bountiful variety were planted at 3 inches $\times 24$ inches and 
TARLE 2.-Efect of various soil acidity factors on yields and composition of beans growing on a lypical Oxisol and Ultisols under humid tropical conditions in Puerto Rico

\begin{tabular}{|c|c|c|c|c|c|c|c|c|c|c|}
\hline \multicolumn{4}{|c|}{ Soil properties } & \multirow{3}{*}{$\mathrm{pH}$} & \multirow{3}{*}{$\begin{array}{l}\text { Yields of } \\
\text { green } \\
\text { beans } \\
\text { pounds/ } \\
\text { acre }\end{array}$} & \multicolumn{5}{|c|}{ Composition of bean leates } \\
\hline \multicolumn{2}{|c|}{$\begin{array}{l}\text { Percent aluminum } \\
\text { saturation }\end{array}$} & \multicolumn{2}{|c|}{$\begin{array}{l}\text { Percent base } \\
\text { saturation }\end{array}$} & & & \multirow{2}{*}{$\begin{array}{c}\text { Ca } \\
\text { (per- } \\
\text { cent) }\end{array}$} & \multirow{2}{*}{$\underset{\substack{\text { (per- } \\
\text { cent) }}}{\mathrm{Mgg}}$} & \multirow{2}{*}{$\underset{\substack{\text { (per- } \\
\text { cent) }}}{P}$} & \multirow{2}{*}{$\underset{\substack{\text { (per- } \\
\text { cent) }}}{N}$} & \multirow{2}{*}{$\underset{(\mathrm{ppm})}{\mathrm{Mn}}$} \\
\hline $\begin{array}{l}\mathrm{NH}_{\text {method }} \\
\text { methe }\end{array}$ & $\begin{array}{l}\text { Summa- } \\
\text { tion of } \\
\text { cations }\end{array}$ & $\underset{\text { method }}{N H_{1} O A C}$ & $\begin{array}{l}\text { Summa- } \\
\text { tion of } \\
\text { cations }\end{array}$ & & & & & & & \\
\hline \multicolumn{11}{|c|}{ Humalas (Ullisol) } \\
\hline $\mathbf{0 - 9}$ & $0-14$ & $60-79$ & $86-100$ & 5.3 & 6,190 & 1.83 & 0.27 & 0.36 & 5.75 & 110 \\
\hline $10-19$ & $15-29$ & $50-59$ & $71-85$ & 4.7 & 5,010 & 1.56 & 0.25 & 0.34 & 5.76 & 160 \\
\hline $20-29$ & $30-44$ & $40-49$ & $56-70$ & 4.5 & 4,350 & 1.49 & 0.21 & 0.44 & 5.94 & 160 \\
\hline $30-39$ & $45-59$ & $30-39$ & $41-55$ & 4.2 & 3,050 & 1.26 & 0.21 & 0.36 & 5.95 & 190 \\
\hline $40-59$ & $60-74$ & $20-29$ & $26-40$ & 3.9 & 1,620 & 1.10 & 0.23 & 0.49 & 6.55 & 210 \\
\hline \multicolumn{11}{|c|}{ Corozal topsoil (Ultisol) } \\
\hline $0-10$ & $0-19$ & $60-79$ & $81-100$ & 5.4 & 9,970 & 2.18 & 0.34 & 0.35 & 5.87 & 121 \\
\hline $11-21$ & $20-39$ & $45-59$ & $61-80$ & 4.7 & 7,940 & 1.57 & 0.29 & 0.30 & 6.11 & 152 \\
\hline $22-32$ & $40-59$ & $30-44$ & $41-60$ & 4.6 & 7,260 & 1.45 & 0.24 & 0.31 & 6.32 & 169 \\
\hline $33-43$ & $60-79$ & $15-29$ & $21-40$ & 4.3 & 3,850 & 0.95 & 0.27 & 0.32 & 6.70 & 184 \\
\hline \multicolumn{11}{|c|}{ Corozal subsoil (Ullisol) } \\
\hline $0-8$ & $0-13$ & $59-68$ & $87-100$ & 5.4 & 10,450 & 2.00 & 0.33 & 0.31 & 5.97 & 122 \\
\hline $9-17$ & $14-27$ & $49-58$ & $73-86$ & 4.8 & 8,780 & 1.61 & 0.36 & 0.32 & 6.14 & 123 \\
\hline $18-26$ & $28-41$ & $39-48$ & $59-72$ & 4.6 & 7,820 & 1.34 & 0.27 & 0.30 & 6.28 & 132 \\
\hline $27-35$ & $42-55$ & $29-38$ & $45-58$ & 4.3 & 4,950 & 1.07 & 0.24 & 0.30 & 6.25 & 150 \\
\hline $36-44$ & $56-69$ & $19-28$ & $31-44$ & 4.2 & 3,240 & 0.88 & 0.25 & 0.30 & 6.78 & 157 \\
\hline \multicolumn{11}{|c|}{ Corozal level (Ullisol) } \\
\hline $0-9$ & $0-12$ & $8+-100$ & $88-100$ & 5.2 & $8,1+0$ & 3.08 & 0.24 & 0.21 & 5.29 & 165 \\
\hline $10-19$ & $13-25$ & $67-83$ & $75-87$ & 4.7 & 7,500 & 2.92 & 0.25 & 0.18 & 5.37 & 234 \\
\hline $20-29$ & $26-38$ & $50-66$ & $62-74$ & 4.6 & 4,060 & 2.44 & 0.25 & 0.20 & 5.67 & 263 \\
\hline \multicolumn{11}{|c|}{ Los Guineos (Ullisol) } \\
\hline $0-8$ & $0-16$ & $55-69$ & $8 t-100$ & 5.3 & 12,140 & 2.39 & 0.31 & 0.17 & 5.79 & 50 \\
\hline $9-17$ & $17-33$ & $40-54$ & $67-83$ & 4.7 & 11,390 & 1.72 & 0.40 & 0.16 & 5.62 & 124 \\
\hline $18-26$ & $34-50$ & $25-30$ & $50-66$ & 4.3 & 9,040 & 1.34 & 0.46 & 0.16 & 5.58 & 149 \\
\hline \multicolumn{11}{|c|}{ Colo (Oxysol) } \\
\hline 1 & 1 & $88-98$ & -.1 & 5.4 & 6,150 & 2.12 & 0.30 & 0.32 & 5.14 & 211 \\
\hline & & $77-87$ & $\ldots$ & 4.8 & 5,920 & 1.91 & 0.29 & 0.31 & 5.13 & 231 \\
\hline & & $66-76$ & & 4.8 & 5,706 & 1.89 & 0.32 & 0.31 & 5.05 & 258 \\
\hline & & $55-65$ & & 4.4 & 4,530 & 1.69 & 0.34 & 0.30 & 5.21 & 267 \\
\hline - & & $4+54$ & - & +.2 & 4,190 & 1.63 & 0.29 & 0.30 & 5.28 & 267 \\
\hline
\end{tabular}

'No exchangeable aluminum at acidity levels studied. 
fertilized with 150 pounds of nitrogen, 150 of phosphoric acid, 150 of potassium, 50 of magnesium, and 30 of zinc per acre in one application at planting. The beans were protected against insects and diseases by spraying periodically.

Leaf samples were taken in each plot following accepted procedures and analyzed for $\mathrm{N}, \mathrm{P}, \mathrm{Ca}, \mathrm{Mg}$, and $\mathrm{Mn}$.

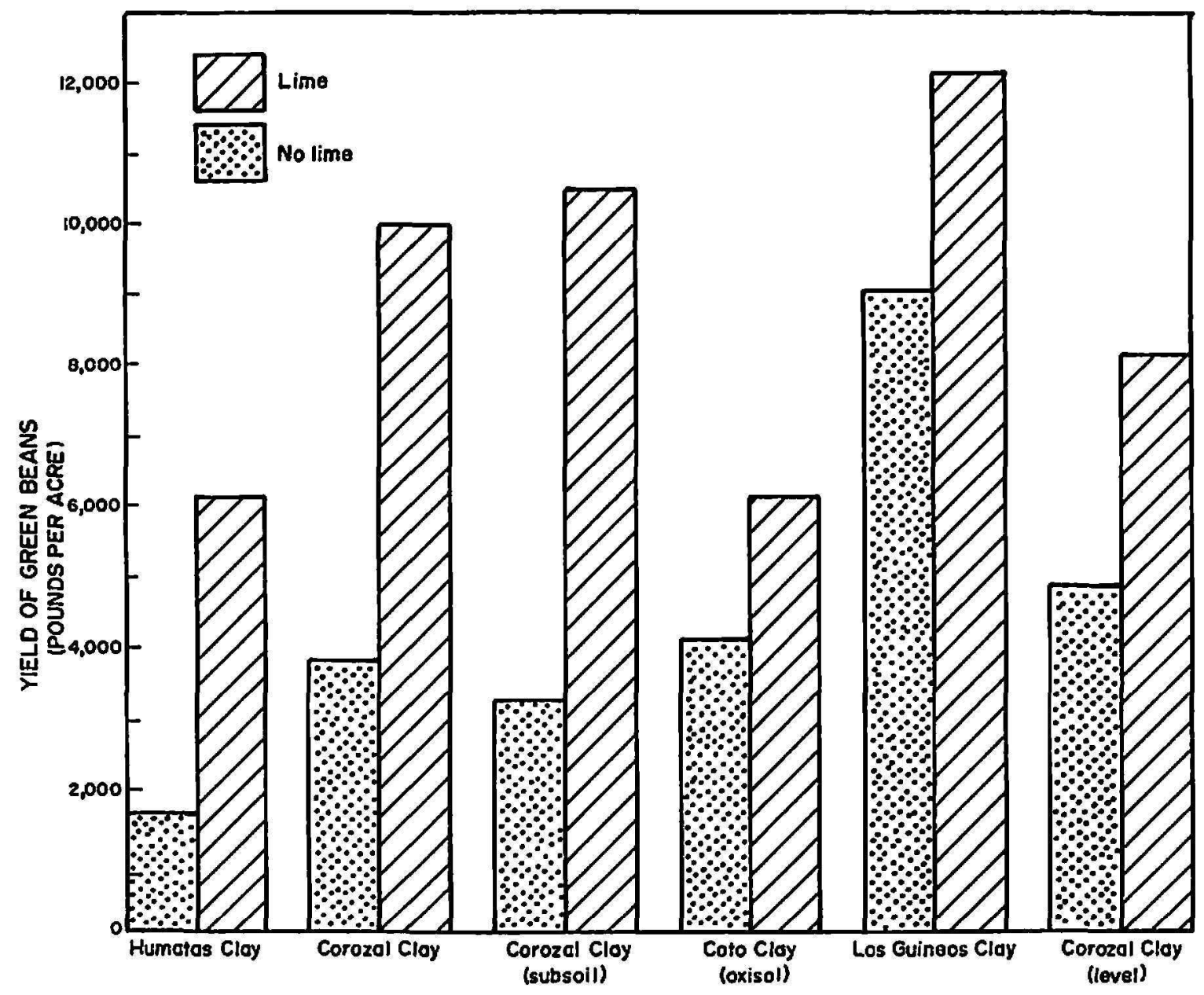

FIG. 1.-Fffect of liming on yields of green beans growing on five typical Ultisols and one Oxisol under humid tropieal conditions in Puerto Rico.

The beans were harvested at the proper stage for consumption as green beans and yiclds produced by each plot determined. Yields were related by regression analysis to soil $\mathrm{pH}$, (xchangeable aluminum, and exchangeable hases and to foliar composition of the beans.

\section{RESULTS AND DISCUSSION}

With proper liming, high yiclds of green beans were obtained in all the (x)eriments (table 2 and fig. 1). Highest yields ranged from about 6,000 pounds per acre on Coto and Humatas clay to over 12,000 pounds on Los (iuineos. Yields on the other soils ranged from about 8 to 10,000 pounds per acre. 


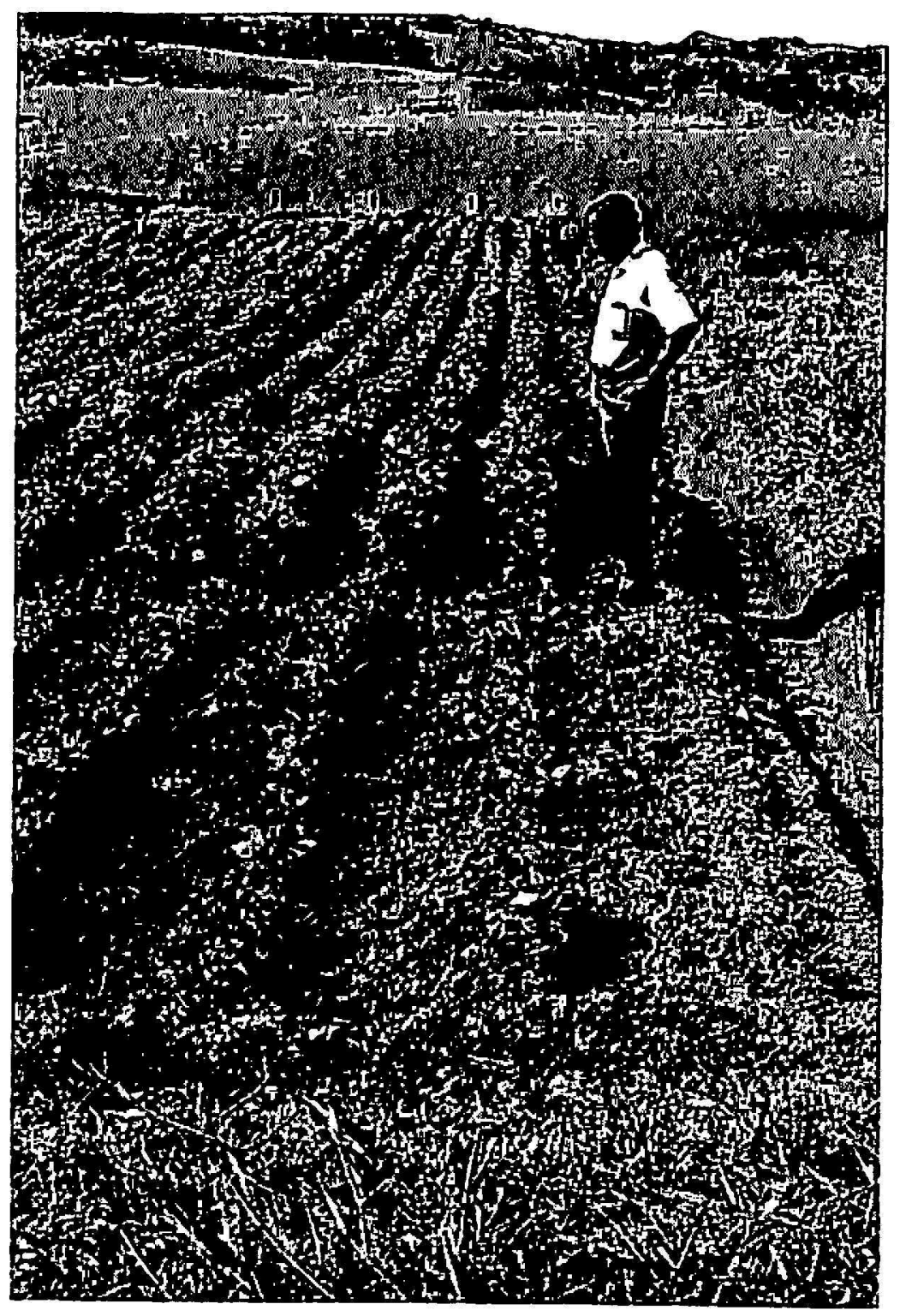

FIG. 2.-Effect of liming a very acid Ultisol (Corozal clay) on growth of otherwise intensively managed, well fertilized beans. Plot in foreground had a $\mathrm{pH}$ of 4.2 with 40-percent aluminum and 25 -percent base $(\mathrm{Ca}+\mathrm{Mg})$ saturation of the exchange complex. Plot in buckground was limed to pH 5.4 with no exchangeable aluminum and 70-percent base saturation.

The large increases in yicld resulting from liming all soils are shown in figure 1. The response of beans to liming Corozal clay is illustrated in figure 2.

Calcium content of the bean leaves increased markedly with increasing soil base content, i.e., lime rates, and with yiclds in all soils (table 2). The close relationship between bean yiclds and calcium content of the leaves on Humatas and on Corozal soil and subsoil are shown in figures 3, 4, and 5. Calcium content of about 2 pereent or more in the leaves was associated with high yiclds. The decrease in calcium content of the leaves with in- 
creasing exchangeable soil aluminum suggests that calcium absorption by the plant was curtailed perhaps through a restrictive effect of aluminum on root development, or on uptake of this nutrient.

Manganese content of the bean leaves increased with increased acidity of all soils (table 2). On most soils, nitrogen content of the bean leaves also tended to increase slightly with acidity. However, neither magnesiumn or phosphorus contents of the bean leaves were affected by liming.

Table 2 shows that the Ultisols had high contents of exchangeable aluminum when acid while the Oxisol (Coto) contained only traces of exchangeable aluminum even when very acid.

On the Ultisols, which contained considerable exchangeable aluminum,

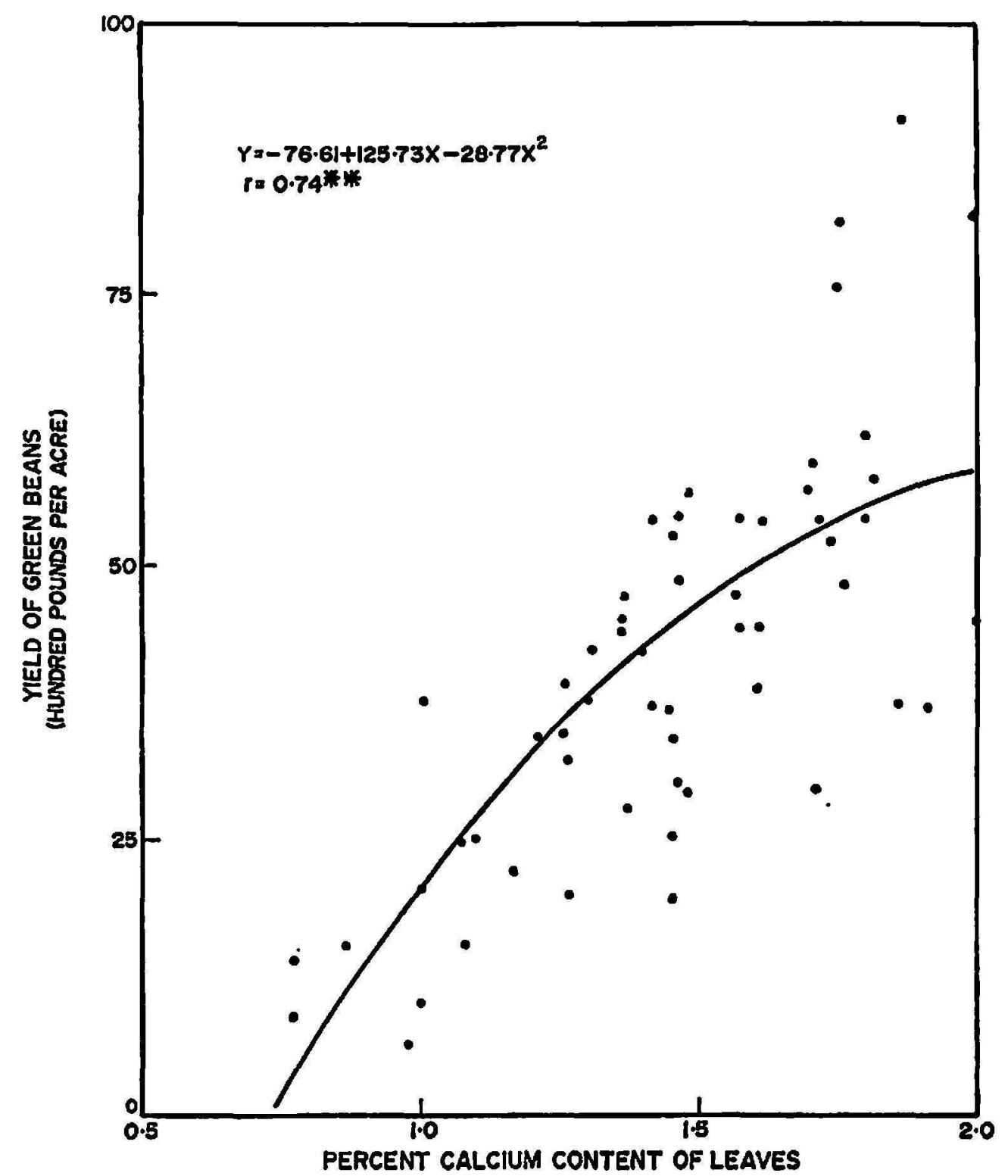

FrG. 3.-Relationship between yields and calcium content of leaves of beans growing on a Humatas clay at Orocovis. 


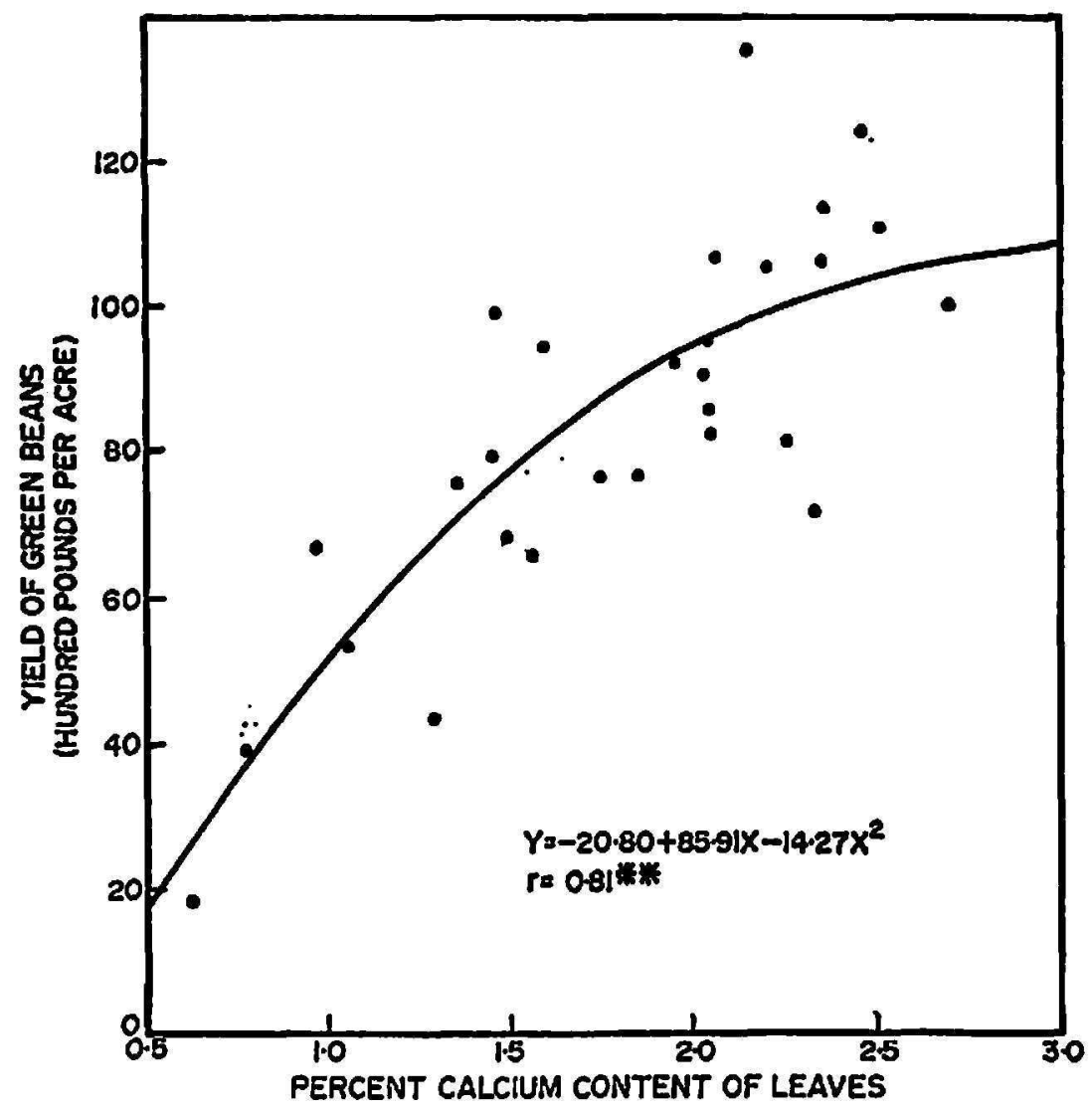

Fro. 4.-Relationship between yields and calcium content of leaves of green beans growing on Corozal clay.

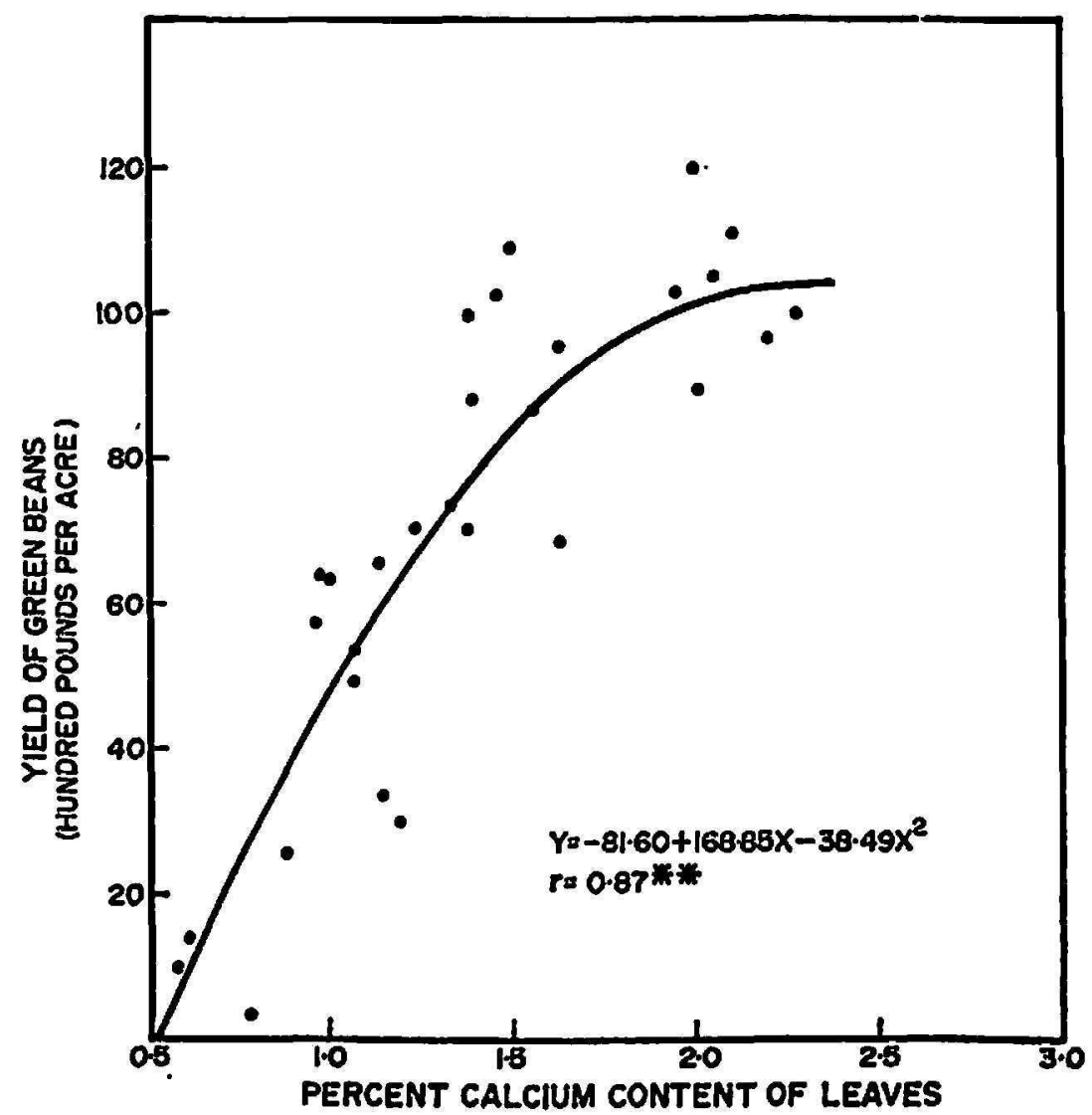

FrG. 5.-Relationship between yields and calcium content of leaves of green beans growing on Corozal subsoil. 


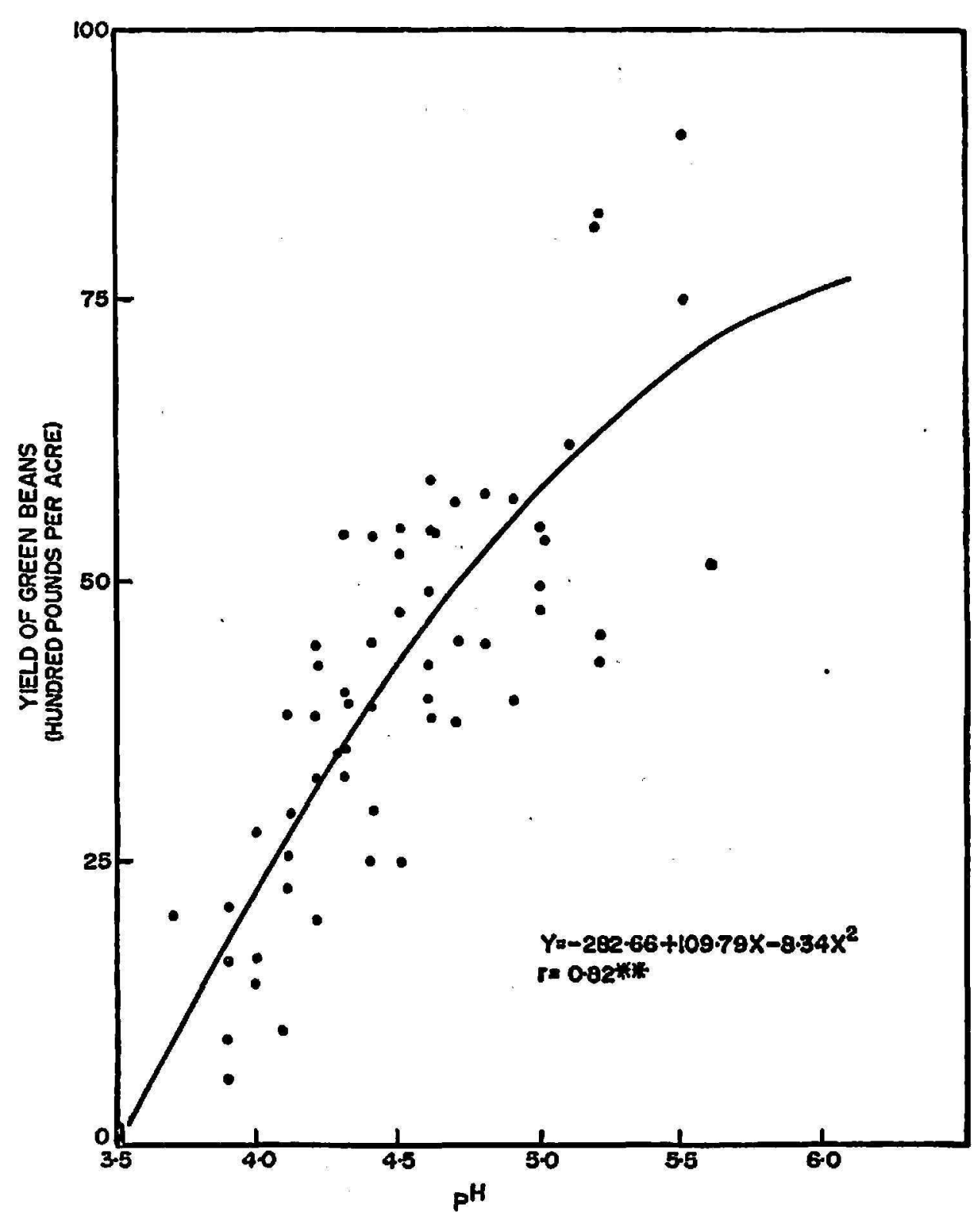

Frg. 6.-Relationship between yields of green beans and pH of a Humatas clay at Orocovis.

bean yields increased with increasing $\mathrm{pH}$ up to somewhat above 5.0 (table 2 and figs. 6, 7, and 8). On the Oxisol (Coto), which contains essentially no exchangeable aluminum but considerable manganese to which beans are sensitive, yields also increased with $\mathrm{pH}$ to about this level.

The close relationship between $\mathrm{pH}$ and yields of beans on Humatas, and on Corozal soil and subsoil, are illustrated in figures 6, 7, and 8.

Table 2 shows that bean yields increased with exchangeable base contents on all soils. The close relationship between percent base saturation and bean yields on Humatas and on Corozal soil and subsoil are shown in figures 9,10 , and 11 . The rate of increase in yields dropped off at about 70-percent base saturation based on cation exchange capacities as determined by the ammonium acetate method. 
Bean yields increased with decreasing exchangeable aluminum content to approximately 0 on all soils (table 2). The close relationship between exchangeable aluminum content and bean yields on Humatas and on Corozal soil and subsoil are shown in figures 12, 13, and 14. Almost no beans were produced when aluminum saturation approached 50 percent.

Exchangeable bases and aluminum thus provide excellent criteria for

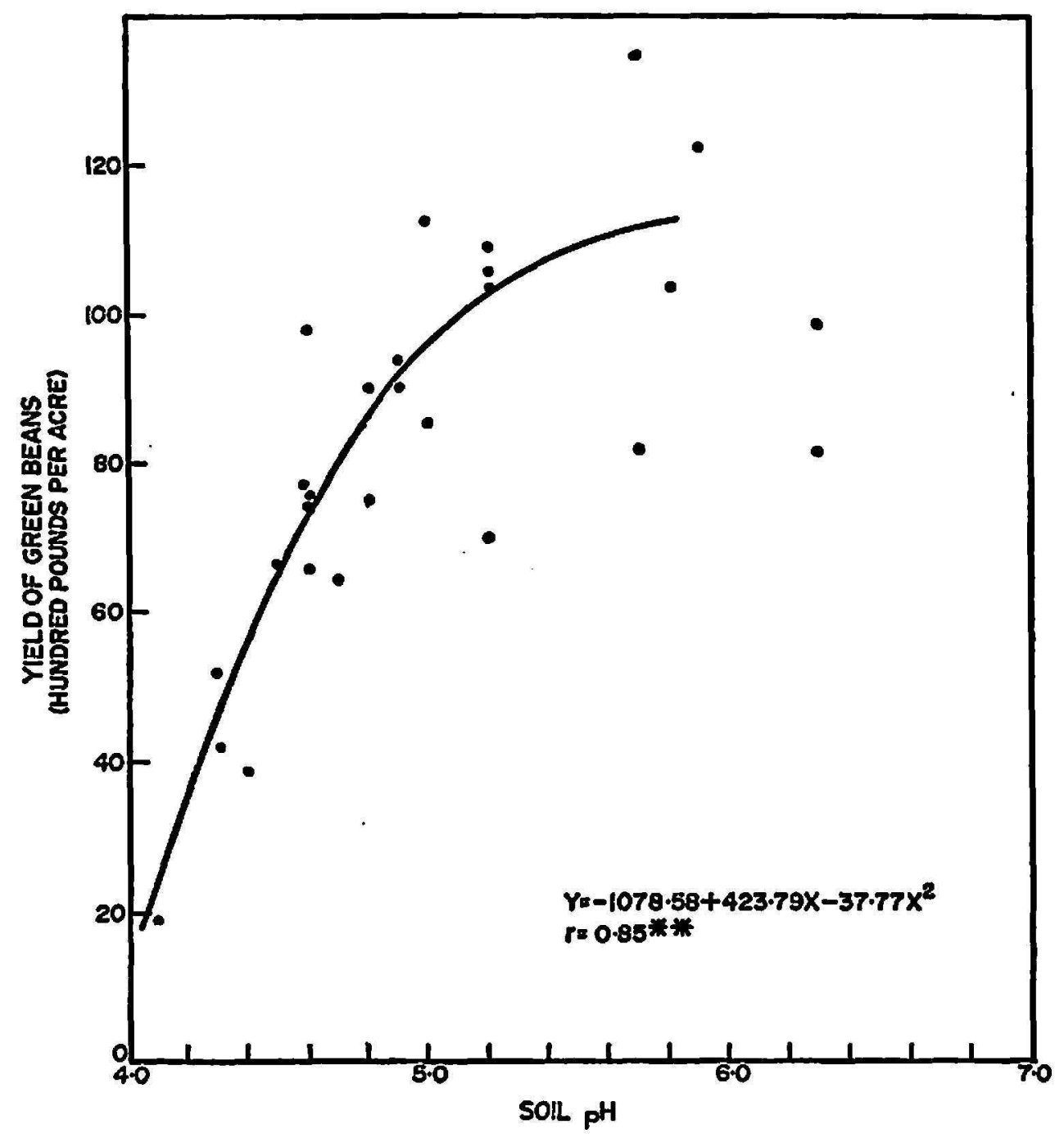

FrG. 7.-Relationship between yields of green beans and pH of a Corozal clay.

determining the need for liming for bean production on the typical Oxisols and Ultisols of the Humid Tropics. To obtain high bean yields, the soils should be limed to about $\mathrm{pH} 5.2$ or 70-percent base saturation based on total exchange capacities determined with ammonium acetate, at which level these soils contain essentially no exchangeable aluminum and little manganese.

Abruña et al. (5) using combined data for these soils found that $\mathrm{pH}$ values increased from about 3.8 with a base saturation of about 20 percent to 


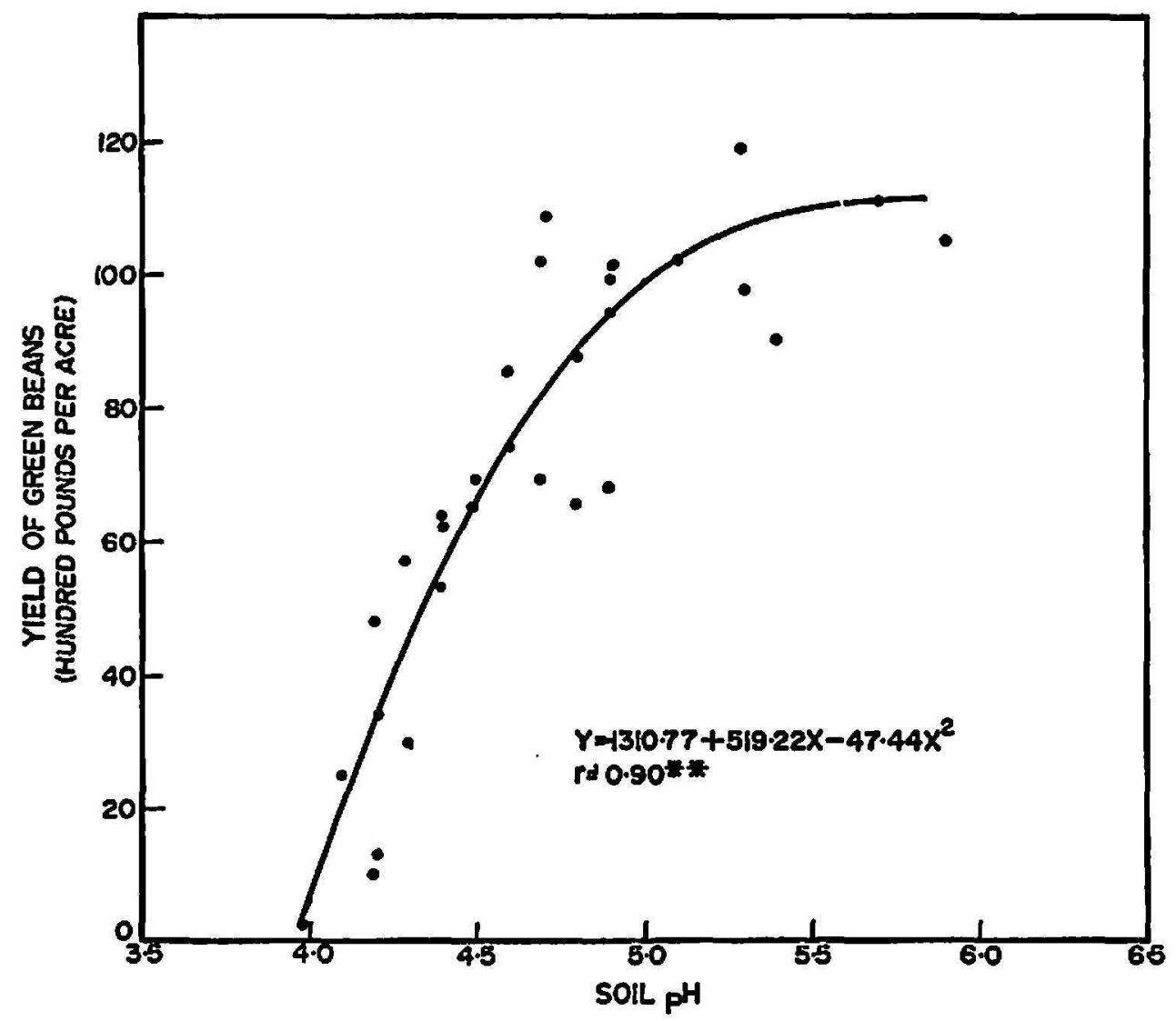

Fra. 8.-Relationship between yields of green beans and pH of a Corozal subsoil.

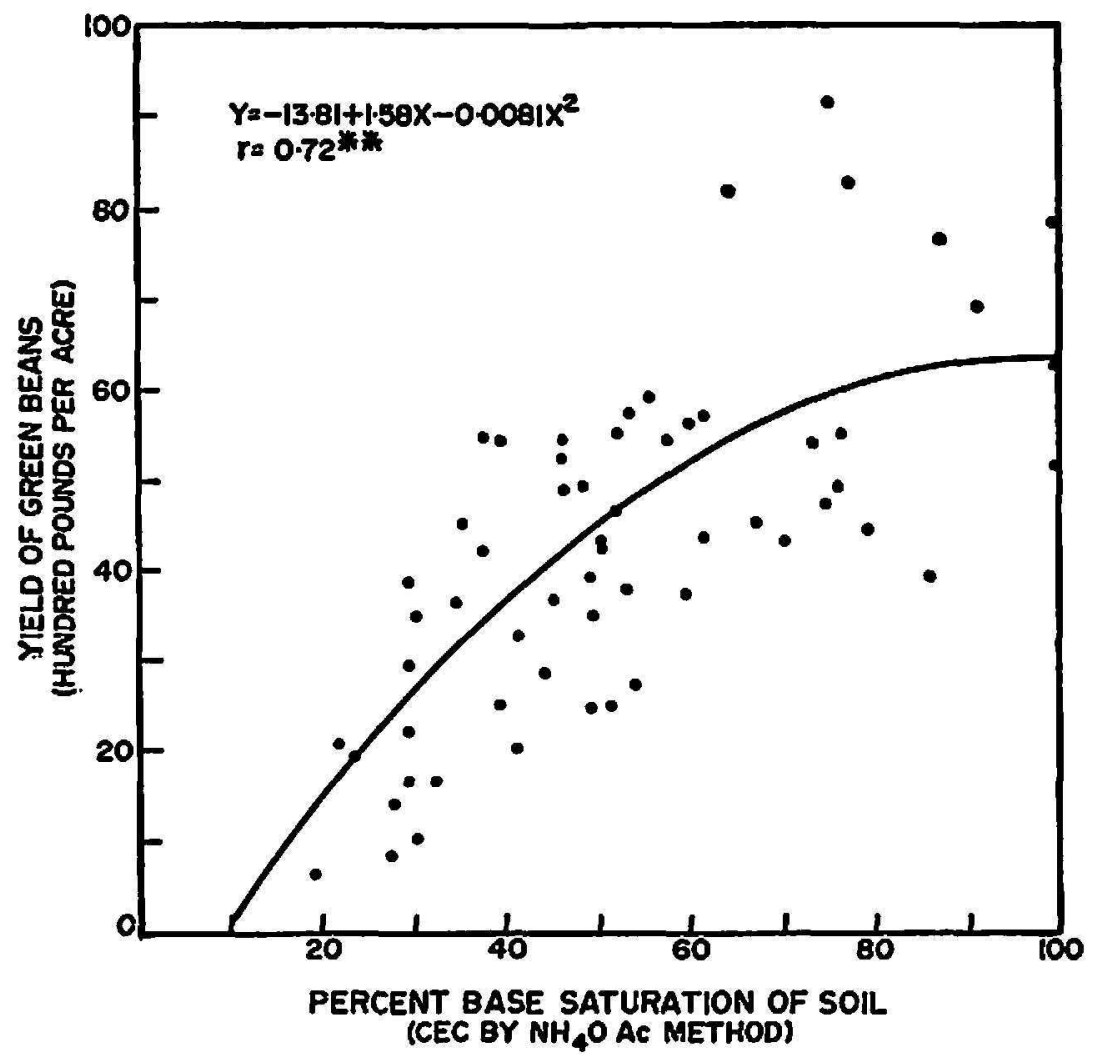

F1G. 9.-Relationship between yields of green beans and percent base saturation of a Humatas clay at Orocovis. 


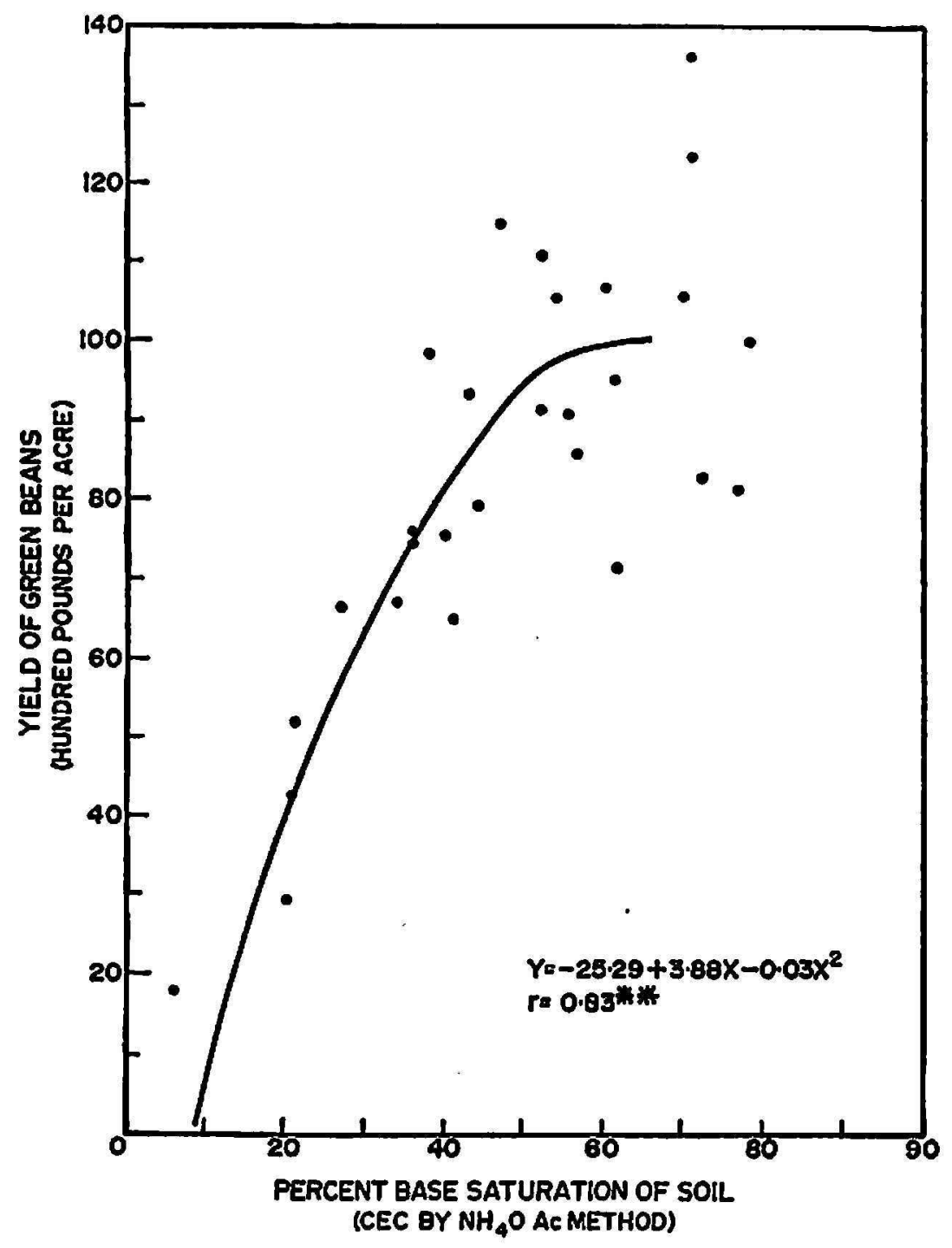

FIG. 10.-Relationship between yields of green beans and percent base saturation of a Corozal clay.

about $\mathrm{pH} 5.0$ with a base saturation of about 70 percent based on cation exchange capacities determined by extraction with ammonium acetate.

The low $\mathrm{pH}$ values in relationship to exchangeable base content of these soils is explained by the probable presence of free salts resulting from heavy fertilization.

These authors also showed that the level of aluminum saturation in these soils, based on total exchange capacities determined with ammonium acetate, decreased from about 40 percent at $\mathrm{pH}$ values of about 3.9 to essentially no exchangeable Al at pH's of about 5.2. Thus, by liming to about $\mathrm{pH}$ 5.2, equivalent to around 70-percent base saturation, exchangeable aluminum and manganese contents of these soils was reduced to non-toxic levels.

These authors showed further that with these soils there is a very close 


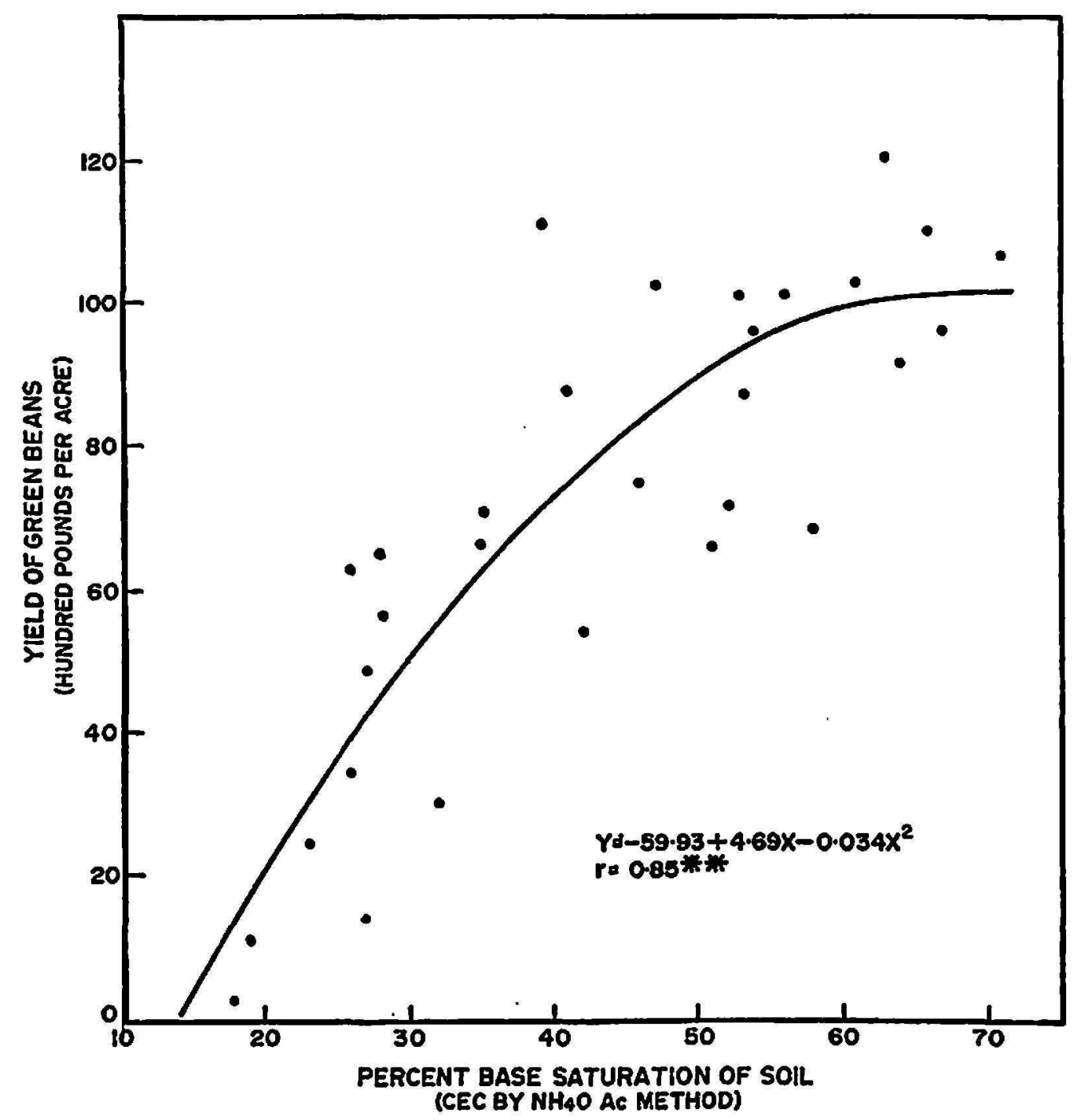

FrG. 11.-Relationship between yields of green beans and percent base saturation of a Corozal subsoil.

relationship between both percent exchangeable aluminum and percent exchangeable base content based on cation exchange capacities determined by either sum of cations at a given $\mathrm{pH}$ or with ammonium acetate at $\mathrm{pH}$ 7. Through this relationship, values based on either method of determining cation exchange capacity can be accurately converted to the other.

\section{SUMMARY}

The effect of soil acidity factors on yields and foliar composition of intensively managed green beans was determined in Ultisols and an Oxisol typical of the Humid Tropics.

Beans responded very strongly to liming on all six soils. Calcium content of the bean leaves increased and manganese content decreased with increasing lime rates and with yields. 


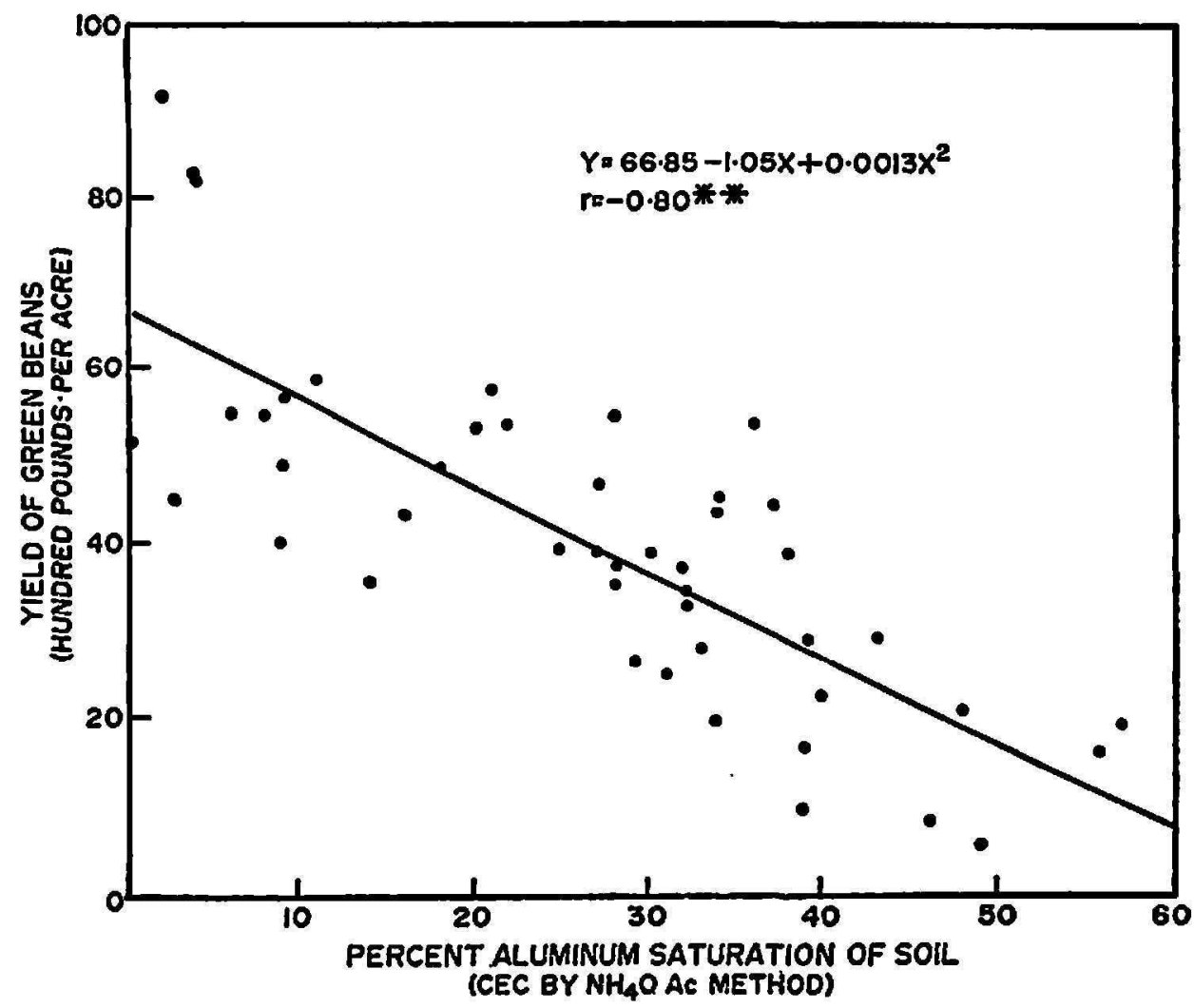

FrG. 12.-Relationship between yields of green beans and percent aluminum saturation of a Humatas clay at Orocovis.

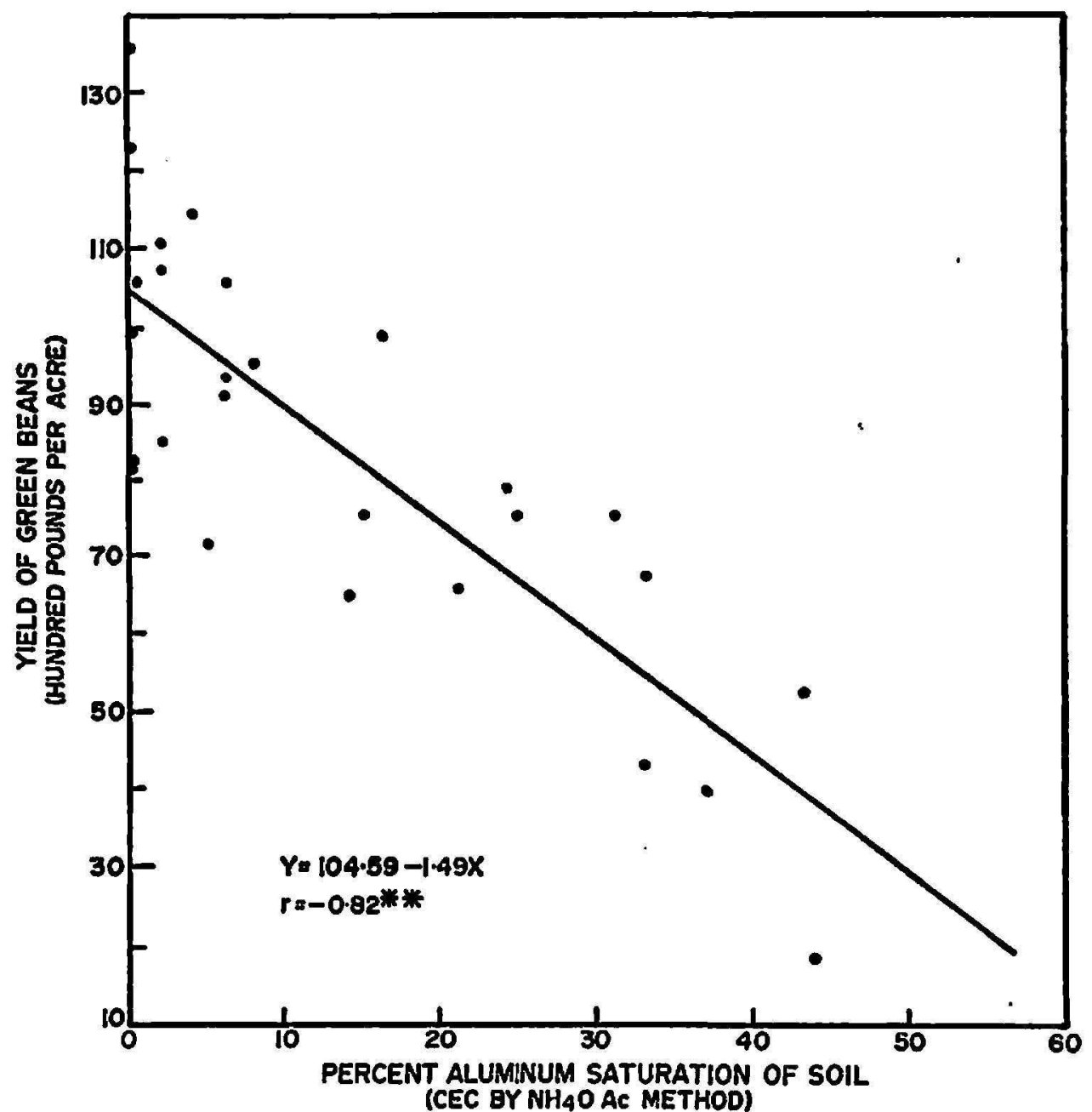

Fra. 13.-Relationship between yields of green beans and percent aluminum saturation of a Corozal clay. 


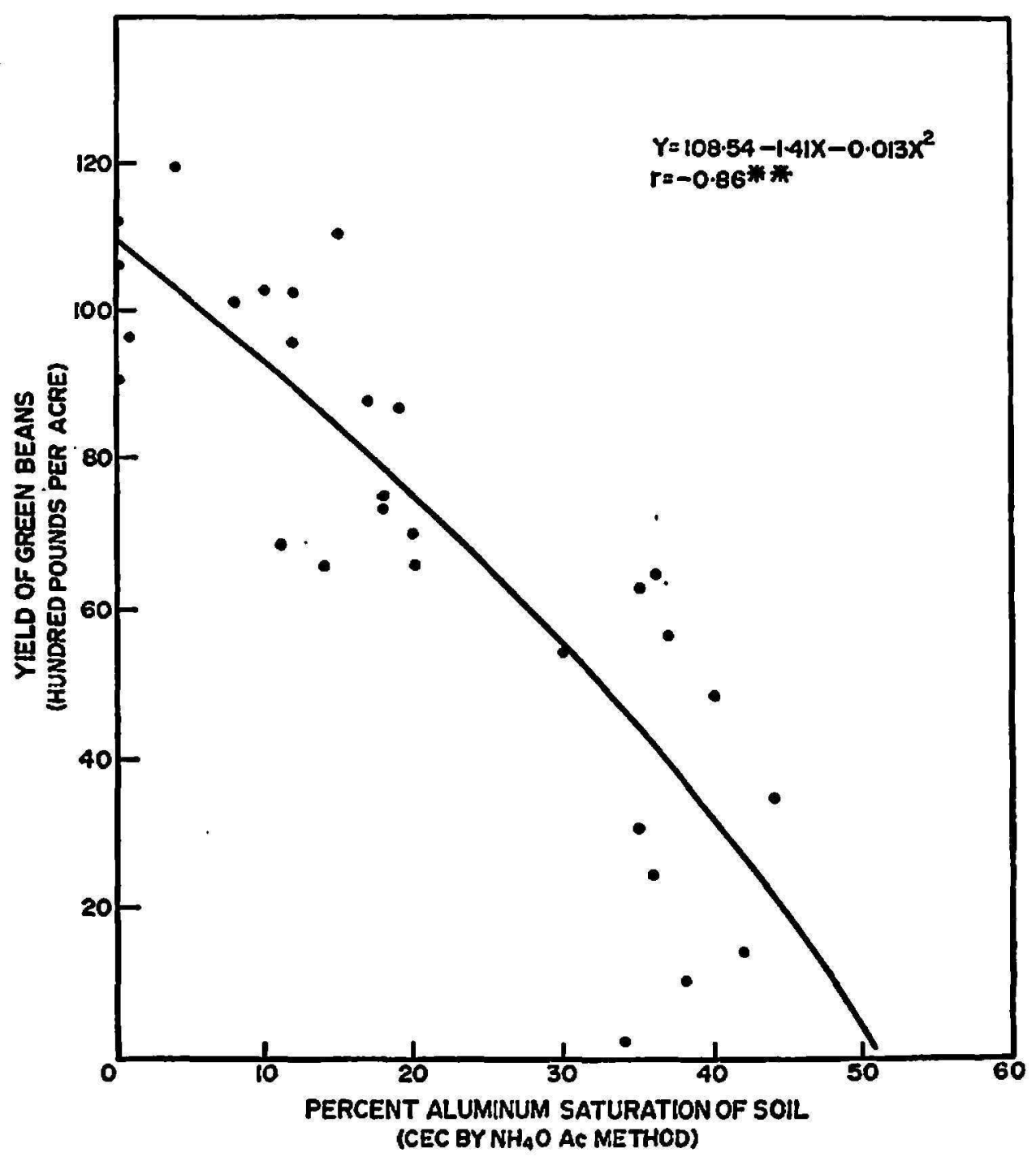

Fra. 14.-Relationship between yields of green beans and percent aluminum saturation of a Corozal subsoil.

Bean yields increased with increasing soil $\mathrm{pH}$ to about 5.2 at which level these soils contained essentially no exchangeable aluminum.

Bean yields increased with increasing exchangeable soil base content to about 70-percent saturation based on cation exchange capacities as determined with ammonium acetate at $\mathrm{pH} 7$.

Bean yields increased with decreasing exchangeable soil aluminum to essentially 0.

Soil $\mathrm{pH}$ and exchangeable base and aluminum contents were effective criteria for liming these soils.

\section{RESUMEN}

Se determinó el efecto de distintos factores asociados con la acidez en Ultisols y un Oxisol típicos de extensas regiones de los Trópicos Húmedos, en la producción y composición foliar de las habichuelas. 
Las habichuelas respondieron al encalado en experimentos de campo realizados en seis suelos. El contenido de calcio en las hojas de las habichuelas aumentó y su contenido de manganeso disminuyó con el nivel de cal y la producción de habichuelas.

La producción de habichuelas aumentó con el $\mathrm{pH}$ hasta aproximadamente 5.2, a cuyo nivel esto suelos apenas contenían aluminio intercambiable.

La producción de habichuelas aumentó con el contenido de bases intercambiables hasta alcanzar un $\mathbf{7 0}$ por ciento de saturación basado en la capacidad total de cambio, determinado ésta con acetato amónico a pH 7.0.

La producción de habichuelas aumentó según disminuyó el aluminio intercambiable en el suelo, lográndose la mayor producción cuando el valor de aquél fue approximadamente 0.

El pH y el contenido de bases y de aluminio intercambiables en el suelo constituyeron criterios adecuados para determinar la necesidad de encalar estos suelos, típicos de regiones extensas en los Trópicos Húmedos para la producción de habichuelas.

\section{LITERATURE CITED}

1. Abruña, F., and Vicente-Chandler, J., Sugarcane yields as related to acidity of a Humid Tropic Ultisol, Agro. J., 59: 530-31, 1867.

2. - - - Becerra, L., and Bosque-Lugo, R., Effects of liming and fertilization on yields and foliar composition of high yielding sungrown coffee in Puerto Rico, J. Agr. Univ. P.R. 49 (4) : 413-28. 1965.

3. - - , and Pearson, R. W., Effects of liming on yields and composition of hesvily fertilized grasses and on soil properties under humid tropical conditions, Soil Sci. Soc. Am. Proc. 28: 657-61, 1964.

4. Abruña-Rodríguez, F., Vicente-Chandler, J., Pearson, R. W., and Silva, S., Crop Response to Soil Acidity Factors in Ultisols and Oxisols-Tobacco, Soil Sci. Soc. Am. Proc. 34 (4) : 629-35, 1970.

5. - , Pérez-Escolar, R., Vicente-Chandler, J., Pearson, R. W., and Silva, S., Response of Corn to Acidity Factors in Eight Tropical Soils, J. Agr. Univ. P.R. 58 (1): 59-77, 1974. 